\title{
Discretionary Fiscal Policy: Review and Estimates for the EU
}

\author{
Roel Beetsma \\ Massimo Giuliodori
}

\author{
CESIFO WORKING PAPER NO. 2948 \\ CATEgory 6: FisCAl POLICY, MACROECONOMICS AND GROWTH
}

FEBRUARY 2010
An electronic version of the paper may be downloaded
- from the SSRN website:
- from the RePEc website:
- from the CESifo website:
www.SSRN.com
www.RePEc.org
www.CESifo-group.org/wp




\title{
Discretionary Fiscal Policy: Review and Estimates for the EU
}

\begin{abstract}
We briefly review the theoretical and empirical consequences of discretionary fiscal policy changes, after which we provide our own estimates for the EU countries. A fiscal expansion raises output and consumption and reduces the trade balance. Moreover, the stimulating effect of higher government purchases is weaker and the trade balance reduction is larger for more open EU economies, consistent with larger leakage effects. Further direct estimates suggest that fiscal expansions in large EU economies have non-negligible consequences for economic activity in the main trading partners. This provides a rationale for the concerted fiscal expansion recently initiated by the European Commission.
\end{abstract}

JEL-Code: E62, F41, F42.

\author{
Roel Beetsma \\ Amsterdam School of Economics \\ University of Amsterdam \\ Roetersstraat 11 \\ 1018 WB Amsterdam \\ The Netherlands \\ R.M.W.J.Beetsma@uva.nl
}

\author{
Massimo Giuliodori \\ Amsterdam School of Economics \\ University of Amsterdam \\ Roetersstraat 11 \\ 1018 WB Amsterdam \\ The Netherlands \\ M.Giuliodori@uva.nl
}

This version: July 1, 2009 


\section{Introduction}

Until the early eighties fiscal policy was widely regarded as a useful tool for economic stabilization. In response to the oil shocks of the seventies many countries relied not only on monetary accommocation but also fiscal expansion. However, those active fiscal policies did not prevent widespread increases in unemployment, while at the same time they resulted in high deficits and rising public debts. This demonstrated ineffectiveness of fiscal policies made many economists sceptical about the usefulness of fiscal policy as a tool for macroeconomic stabilization. Nevertheless, politicians continue to view an active fiscal policy as a useful instrument for solving their economic problems. Quite recently, though without success, Japan used large fiscal expansions in order to escape from its liquidity trap. Further, after they secured membership of the Euro-area, a number of countries relaxed fiscal policy, sometimes implementing tax cuts (such as in the case of Germany and France). The U.S. has experienced several rounds of fiscal expansion over the past decades. In 2008, when the current crisis was still in its relatively early stages, the U.S. implemented a 150 billion dollar fiscal stimulus package (roughly one percent of the U.S. gross domestic product), of which two-thirds were intended for tax rebates to private individuals and onethird for tax cuts for firms. The stimulus was applauded by some of the most prominent economists as well as the IMF, normally a promotor of fiscal austerity. Since then an even much larger amount of public resources has been spent, much of it to stabilise the financial sector, but also a large share to support the "real economy". Also Europe has raised public spending in response to the crisis. November 2008, the EU presented its European Economic Recovery Plan (EERP) aimed at a discretionary fiscal stimulus of about 1.5\% of the EU GDP, with 1.2\% of GDP coming from the Member States.

While the consequences of monetary policy changes have been widely studied in the literature and there is substantial consensus about their effects, we know relatively little about the effects of fiscal policy changes. We are not even sure about the direction of the responses of some variables, let alone the magnitude of those responses. Even theoretically, the consequences of fiscal expansion are ambiguous, depending on the type of model employed. In particular, there is a rather sharp disagreement whether an increase in government purchases has a positive or negative effect on consumption. Empirical analysis also produces controversy, because of the complications involved in such analysis, in particular the identification of the shocks and potential anticipation effects of fiscal policy changes. Nevertheless, armed with the tools used for monetary policy analysis, academic researchers have regained interest in the empirical analysis of fiscal policy. 
This article starts by reviewing the theoretical and empirical consequences fiscal expansion in closed and open economies. We focus mostly on the short-run consequences of fiscal expansions, because the main question we are interested in is to what extent discretionary fiscal policy is able to stabilize the business cycle. In this respect, our paper contrasts with Gemmell et al. (2009) and Heady et al. (2009) who are more concerned with the long-run effects of fiscal policy, while, moreover, they focus on the long-run economic consequences of the structure of the tax-spending system. We also present our own estimates (based on panel vector autoregressions (VARs)) of changes in government purchases for the EU economies, paying specific attention to the behaviour of the components of GDP, the budget balance, the trade balance, the role of trade openness and cross-border spill-overs. This latter aspect is quite important as it has been argued that coordinated fiscal responses in Europe would be more effective in dealing with the crisis than unilateral policy initiatives.

The remainder of this paper is structured as follows. In Section 2 we briefly discuss the theoretical consequences of discretionary fiscal expansions in closed and open economies. Section 3 summarises recent empirical evidence, while Section 4 discusses European fiscal policy in connection to the crisis. In Section 5 we present our own estimates of the consequences of government purchases increases for the EU. Section 6 concludes the main text.

\section{Discretionary fiscal expansions - theory review}

Not surprisingly, what theory says about the consequences of changes in fiscal policy depends to a large extent on the specific framework employed. We are mostly interested in the short-run effects of fiscal expansions on output, consumption and investment. We distinguish between closed and open economies. For the latter we are also interested in how fiscal expansions impact on variables such as the trade balance and the real exchange rate.

\subsection{Fiscal expansions in closed economies}

Nowadays, fiscal policy is studied in the context of inter-temporal models with micro-foundations. Baxter and King (1993) conduct a number of fiscal policy experiments in a standard neo-classical model. Taxes are lump sum, hence, for a given path of government expenditures the time profile of tax revenues does not matter. Consider an increase in government consumption. The discounted value of future tax payments rises, which generates a negative wealth effect and induces individuals to reduce both private consumption and leisure. The labour supply increases, hence real wages fall 
and total output expands. Moreover, the rise in employment raises the (marginal) productivity of capital and induces more private investment. Obviously, the described effects are stronger when the policy shock is permanent instead of temporary. The authors find that a permanent government purchases increase can generate an output multiplier larger than unity both in the short and the long run. However, if the increase in government consumption is financed by distortionary taxes, labour supply and output rise by less, or may even fall, as Fatás and Mihov (2001) show in a closely related experiment. Finally, a boost to public investment (instead of public consumption) produces additional positive effects on the economy by raising the productivity of capital and labour. Private consumption may then even increase, although with some lag.

Burnside et al. (2004) introduce a number of features into the neo-classical model to improve the replication of estimated responses to a government purchases shock. In particular, they assume that there are costs to changing the capital stock, while there is "habit persistence" in consumption in the sense that individuals want to maintain a given consumption level. This way, changes in employment and investment exhibit a more drawn out pattern after the policy shock.

The most distinguishing feature of the neo-classical model is that it tends to predict a fall in private consumption following an increase in government purchases, while a large part of the empirical literature (discussed below) finds the opposite effect. ${ }^{1}$ The main obstacle in reconciling theory with this (claimed) empirical observation is the rightward shift of the labour supply curve, which for a given labour demand curve implies a lower wage and, hence, less consumption. Hence, to generate a positive effect on consumption it is necessary (though not always sufficient) to have a mechanism that also shifts the labour demand curve to the right. An example is found in Devereux et al. (1996), where higher government spending raises the equilibrium number of firms in intermediate goods sectors characterized by increasing returns to specialization. The productivity of all firms in the sector rises and the resulting outward shift in the labour demand may dominate the increase in the labour supply, hence produce a higher real wage and an increase in consumption.

Ravn et al. (2006) introduce “deep habits” into a model with monopolistic competition in goods production. "Deep habits" refer to habit formation about the amount of consumption of individual goods (rather than about aggregate consumption as is standard under the assumption of habit persistence). The model implies that demand for a specific good is composed of a price elastic component (as in standard monopolistic competition models) and an inelastic component that does not react to price changes. An increase in aggregate demand raises the weight of the elastic component, inducing producers to lower their prices. An increase in government consumption

\footnotetext{
${ }^{1}$ There are ways, though, to reconcile the neo-classical model with a positive private consumption response to a government purchases increase. Linnemann (2006) provides an example based on the way utility from private consumption and leisure is specified.
} 
produces the standard negative wealth effect on the one hand, resulting in a higher labour supply. On the other hand, the higher aggregate goods demand leads producers to lower goods prices, thereby also generating more demand from private agents. The higher demand for goods translates into more demand for labour and, hence, an increase in the real wage that may dominate the wage effect of the higher labour supply.

An alternatively route to generating a positive consumption response to a government purchases increases is to use a New-Keynesian framework with monopolistic competition en nominal rigidities. These could take the form of pre-set prices for products. Such a framework has originally been used to study the effects of monetary policy shocks, but recently it has also become a vehicle for studying fiscal policy (see, for example, Beetsma and Jensen, 2005). As before, an increase in government purchases generates a negative wealth effect (with a positive effect on the labour supply) owing to the rise in tax payments. However, with sticky prices and because the price of output exceeds the marginal cost under monopolistic competition, an increase in the demand for goods will be met with an increase in the supply of output. At the pre-set price level, firms are prepared to supply the additional output as long as the price is not exceeded by the marginal cost. Hence, the demand for labour increases after the government purchases shock and this pushes the real wage rate up, ceteris paribus. However, even if the overall effect on the real wage is positive, this does not guarantee a (substantial) positive effect on consumption. The reason is that consumers have an incentive to save at least part of the higher real wage for the future. Owing to the rise in (current and future) taxes, consumption may still fall. Some additional imperfection would then be needed to generate higher consumption. Therefore, Galí et al. (2007) assume that there is a group of “rule-of-thumb” consumers who consume their entire disposable income (income minus taxes) and, thus, do not save. Hence, these consumers spend immediately the entire increase in their real wage. Provided that this group of consumers is sufficiently large, the net effect on current consumption may be positive.

To summarise, Table 1 provides a systematic overview of the macro-economic effects of an increase in government purchases in different settings. 
Table 1: Predicted effects of a government purchases increase in a closed economy

\begin{tabular}{|c|c|c|c|c|c|c|}
\hline & $Y$ & $C$ & $r w$ & $L^{s}$ & $L^{d}$ & $L$ \\
\hline Neoclassical & $\uparrow$ & $\downarrow$ & $\downarrow$ & $\uparrow$ & 0 & $\uparrow$ \\
\hline Deep habits & $\uparrow$ & $\uparrow$ & $\uparrow$ & $\uparrow$ & $\uparrow$ & $\uparrow$ \\
\hline $\begin{array}{c}\text { NK - nominal } \\
\text { rigidities only }\end{array}$ & $\uparrow$ & $\downarrow$ & $\uparrow$ & $\uparrow$ & $\uparrow$ & $\uparrow$ \\
\hline $\begin{array}{c}\text { NK - rule - of - } \\
\text { thumb }\end{array}$ & $\uparrow$ & $\uparrow$ & $\uparrow$ & $\uparrow$ & $\uparrow$ & $\uparrow$ \\
\hline
\end{tabular}

Notes: this table is based on Pappa (2006). The symbols and mnenomics are as follows: $Y=$ output, $C=$ consumption, $r w$ = real wage, $L^{s}=$ labour supply, $L^{d}=$ labour demand, $L=$ employment, "NK" = New-Keynesian.

\subsection{Fiscal expansions in open economies}

While we are still interested in how fiscal expansions affect output, consumption and investment, with an open-economy framework we can also explore the consequences for the trade balance and its components. For example, one may be interested whether the "twin deficits hypothesis" holds, that is, whether a fiscal expansion produces a simultaneous deterioration in the public budget and the trade balance. Much of the policy discussion has always taken place in the context of the Mundell-Fleming model. The model features price stickiness and predicts that a fiscal expansion in an open economy with a flexible exchange rate crowds out net exports through a real exchange rate appreciation and leaves GDP unaffected. With a fixed exchange rate, the money supply expands and GDP increases, while net exports remain unchanged. However, the model is not based on micro-foundations and the longer-term consequences of the fiscal expansion are ignored. Recent analyses generally use micro-founded models and, again, it is important to distinguish between neoclassical and New-Keynesian frameworks. However, the move to an open economy also introduces other relevant considerations. One is the size of the economy relative to the rest of the world. A second factor concerns the degree of international risk sharing through asset markets (i.e., how internationally complete they are). Other factors are the degree of trade openness of the economy, the substitutability between home and foreign products and the degree of "home bias" in government purchases (that is, the relative share of domestic products in government purchases).

Consider a neoclassical open economy setting, such as Baxter's (1995), and assume an economy (denoted as "Home”) of non-negligible size relative to the rest of the world ("Foreign"). The two countries produce perfectly substitutable goods. Following a (permanent) positive shock to 
government purchases, individuals again start to consume less and work more, thereby boosting the marginal productivity of capital and stimulating investment. The rise in the world interest rate due to the enhanced productivity of capital deepens the fall in consumption (and leisure) to allow for a higher subsequent growth rate of consumption. With complete international asset markets, the fall in consumption is perfectly shared with Foreign. Hence, also the output and investment responses in Foreign are the same as in Home. Finally, the combination of reduced public saving and increased private saving and investment produces an overall deterioration of the trade balance. When international asset markets are incomplete, such that only a risk-free bond is traded, the wealth effect is borne by Home. Hence, labor input in Home rises by more and the fall in the real wage will be larger than under complete markets, while the opposite is the case in Foreign. ${ }^{2}$ Also the size of Home is important. If it is very small relative to the rest of the world, then under internationally complete asset markets the government purchases shock has a negligible effect on Home because the entire world shares in the effect. Under incomplete markets, Home has again to absorb the full wealth effect.

In contrast to Baxter (1995), Corsetti and Müller (2008) assume that Home and Foreign products are only imperfectly substitutable, implying that the composition of government purchases is important. The authors assume that they are entirely spent on domestic products, an assumption that is generally quite reasonable as government purchases are mostly made up of civil servants' salaries and public procurement tends to be biased to domestic firms. With complete international asset markets the consumption fall following the government purchases increase is again shared with foreigners. However, because the spending increase falls on Home products, Home's real exchange rate appreciates and the standard international risk-sharing condition implies that the fall of Home consumption exceeds that of Foreign. ${ }^{3}$ Also, the Home terms-of trade improve.

Besides the standard positive effect on investment (due to the wealth effect) and the negative effect from rise in the real interest rate, there is an extra stimulus to investment, because the price of the final goods produced with the additional investment equipment rises relative to the price of investment goods, which have become cheaper because they are partly constructed from imports.

The authors also explore the role of openness. More openness dampens the consumption fall, because it dampens the real interest rate increase. Intuitively, with better terms-of-trade today, the price of consumption today is relatively low compared to what it will be in the future (when the terms-of-trade has returned to its original value) and the more so, the larger the consumption share

\footnotetext{
${ }^{2}$ Foreign labour input still rises due to the rise in the world interest rate. However, foreign investment falls.

${ }^{3}$ The condition is (after some normalisation), $u_{C}^{F} / u_{C}^{H}=R E R$, where the left-hand side is the ratio of the marginal utilities of Foreign $(F)$ and Home $(H)$ consumption, while the right-hand side is the real exchange rate, defined such that an increase means a depreciation of Home real exchange rate.
} 
on foreign goods. Hence, while the real interest rate (being the price of today's consumption in terms of future consumption) still rises after the shock, it does less so in more open economies. The more moderate rise in the real interest rate increase affects the investment response positively. This is enforced by the larger increase in the price of final output relative to the cost of the investment good. Obviously, the positive effect of openness on consumption and investment implies a larger trade balance deterioration after the policy shock.

In a related framework, Müller (2008) explores the role of the degree of substitutability between Home and Foreign products when the government purchases increase again falls entirely on Home products. This real exchange rate appreciation causes an "expenditure switching effect" with Home and Foreign consumers switching towards Foreign products. The switch is larger the higher is the elasticity of substitution between Home and Foreign products. The increase in output will be correspondingly smaller and the fall in the trade balance will be larger.

\section{Discretionary fiscal expansions -review of empirics}

The main obstacle in empirical fiscal policy analysis is to identify exogenous and unexpected fiscal events. In this regard, the literature has followed two major approaches. One is to explore the effects of specific events that can reasonably be assumed exogenous - see, for example, Ramey and Shapiro (1998), Edelberg et al. (1999) and Burnside et al (2004). The most obvious examples are military expenditures in response to war or the threat of a war. The other major approach is to set up a structural vector autoregression (SVAR) model. The model explains a system of macroeconomic variables by their lags and exogenous shocks to the variables in the system. The "trick" is to find an appropriate set of restrictions among the variables, for example motivated by economic theory or institutional features, to uncover the exogenous shocks from the data and estimate the parameters. Because the estimates that we show below build on the second approach, we shall limit our literature discussion to work in this direction.

\subsection{Closed-economy models}

Blanchard and Perotti (2002) use an SVAR approach to study the effects of fiscal policy shocks in the U.S. after World War II. Their main identifying restriction is to assume that government purchases do not contemporaneously react to output. With quarterly observations this seems a reasonable assumption. Their work also makes use of detailed institutional information about the tax system, as well as information on the elasticities of taxes and transfers to income. They find that 
an increase in government purchases affects economic activity positively with a multiplier that tends to be close to unity, while an increase in net taxes has the opposite effect. Further, an increase in government purchases boosts consumption, while both an increase in government purchases and a net tax increase exert a negative effect on investment.

Studying the consequences of a government purchases shock for the U.S., Fatás and Mihov (2001) essentially confirm the results of Blanchard and Perotti (2002), except that they find a (lagged) positive effect on investment. They also explore responses to shocks in the various components of government purchases (public wage spending, non-wage spending and government investment). The main result is that in all instances consumption goes up and that this increase is most pronounced in the case of a shock to public wage spending.

Mountford and Uhlig (2009) identify shocks by imposing theory-motivated signs on the responses to these shocks. Again, they apply their methodology to the U.S. They find that a surprise deficit-financed tax cut is the best fiscal policy to stimulate the economy. A deficit-financed increase in government purchases has only a weak positive effect on activity. The response of consumption is small and only significant on impact, while both residential and non-residential investments are crowded out.

\subsection{Open-economy models}

Somewhat surprisingly, Kim and Roubini (2008) find for the U.S. that an increase in the budget deficit produces a short-run improvement of the current account, regardless of whether the budgetary expansion is caused by an increase in public spending or a reduction in taxes. They explain this finding by arguing that the direct effect of the expansion on the current account is dominated by the extra private saving (to pay for the higher future taxes) and the rise in the interest rate, which depresses investment.

There is also related work for the OECD and the EU. Using quarterly data, Monacelli and Perotti (2006) and Ravn et al. (2007) estimate impulse responses after an increase in government purchases for Australia, Canada, the U.K. and the U.S. Estimations by the former are on a countryby-country basis, while the latter use a panel VAR. The sample periods are roughly the same. Both studies find that an increase in government purchases produces output and consumption increases and a trade balance deterioration. In contrast to what most of us might expect, the shock also produces real exchange rate depreciation.

Bénétrix and Lane (2009) estimate how shocks to different components of government purchases affect the real effective exchange rate of eleven EMU countries. A positive shock to 
aggregate government purchases produces an appreciation, while this is also the case for an increase in public investment and an increase in wage government consumption, but not for an increase in non-wage government consumption. An application of their methodology to the five-country sample used by Monacelli and Perotti (2006) and Ravn et al. (2007) does indeed confirm their finding that the real exchange rate depreciates after a government purchases increase. This leads them to speculate that this sharp difference in results may be traced to the exchange rate regime and monetary policy. The EMU group has been characterised by (quasi-) fixed exchange rates over the past decennia, while the other group of countries maintains flexible exchange rates.

For a large set of OECD countries over the period 1960-1995, Lane and Perotti (1998) link the trade balance and its components to the different components of the public budget. They find that the composition of a change in fiscal policy and the exchange rate regime both matter for the effects on the external account. In particular, higher wage government consumption produces a fall in exports and a deterioration of the trade balance, especially under flexible exchange rates. ${ }^{4}$ Imports are also negatively affected, or unaffected, depending on the regression specification. Related analysis by Lane and Perotti (2003), also for the OECD, essentially confirms these results. They also find that an increase in non-wage government consumption has only a small effect on the traded sector.

\section{EU fiscal expansion to combat the crisis}

With its EERP presented end of November 2008 the EU intends to respond to the current economic crisis with a discretionary fiscal expansion of $1.5 \%$ of EU GDP in order to mitigate the fall in economic activity. The EU Member States have committed in total 1.2\% of their GDP (170 out of the total of 200 billion euros), while the remainder is supposed to come from EU funds. The support for the plan has not been wholehearted, with some countries (in particular, Germany) claiming that they are already providing enough stimulus by simply letting their automatic stabilisers operate. Indeed, countries with larger automatic stabilisers implicitly provide more effort, also for the "European common good", due to trade spill-overs to other countries. The effects of the automatic stabilisers alone will already produce unprecedented deterioration of the public budgets. Although the European Commission, the guardian of the Stability and Growth Pact (SGP), ${ }^{5}$ now takes a tolerant approach in their assessments of the so-called Stability and Convergence Programmes,

\footnotetext{
${ }^{4}$ With a fixed exchange rate regime the tendency for the real exchange rate to appreciate will be suppressed, hence the trade balance is better protected against the shock (as is also predicted by the Mundell-Fleming model).

${ }^{5}$ The SGP aims at keeping public deficits in the EU below 3\% of GDP. The Pact has a preventive arm and a dissuasive arm aimed at the punishment of the violators of the $3 \%$ criterion. The so-called Stability and Convergence Programmes are part of the preventive arm.
} 
clearly the plunge in fiscal positions - with deficits reaching more than $10 \%$ of GDP in some cases - has aggravated sustainability concerns. Recently, the IMF has projected the public debt of the ten leading rich countries, among them some EU countries, to rise above $110 \%$ of GDP by 2014. Two further considerations may have fed the reluctance to active fiscal expansion. First, there is considerable uncertainty about the size of the effects of the stimulus and, second, with most economies being highly open, the benefits of active national fiscal expansion may largely leak away. Therefore, it is not surprising that the EERP aims at a coordinated fiscal expansion.

\section{Estimates for the EU}

Before turning to the actual estimation, some discussion about the methodology is warranted. In the absence of any "active" policy intervention, the public budget moves automatically with the economic cycle. Government transfers, such as unemployment benefits, increase as the economy slows down and unemployment rises, while at the same time tax revenues on labour, capital income and consumption fall. The opposite happens when the business cycle is improving. These automatic movements of the government budget resulting from the business cycle are referred to as the cyclical component of the budget. The structural component of the public budget (or the fiscal stance) is obtained by subtracting the automatic cyclical component from the actual budget. However, also this structural component may be systematically linked to the economic cycle. For example, the government may reduce tax rates whenever activity falls below potential. The component could also be systematically linked to other variables such as the stock of outstanding public debt or inflation. These systematic responses will be referred to as the endogenous structural component. The other part of the structural budget is called the exogenous component. Examples are an increase in public purchases to finance a war or a politically-motivated increase in transfers to the population prior to an election.

We extend the analysis in Beetsma et al. (2008) and explore the consequences of unexpected changes in government purchases for domestic activity, its components, the public budget and the external balance for a sample and sub-samples of 14 EU countries over the period 1970-2004. We also investigate the potential spill-overs on activity in the EU trading partners. The sample countries are Austria, Belgium, Denmark, Finland, France, Ireland, Italy, Germany, Greece, the Netherlands, Portugal, Spain, Sweden and the U.K. A more detailed description of the sample and the data sources is found in the Appendix.

Following Beetsma et al. (2008) and Bénétrix and Lane (2009), but in contrast to some related literature, we use annual instead of quarterly data. This has a number of advantages. First, 
the shocks we uncover with annual data may be closer to the actual shocks, because new fiscal impulses do not usually take place at the quarterly frequency, but more likely in the new budget and possibly in mid-year budgetary revisions. Also, the effects of the potential anticipation of fiscal policy changes should be less relevant, because the uncovered shocks are more likely to be truly unanticipated. ${ }^{6}$ After all, a given policy shock is less likely to be anticipated one year before it actually takes place than one quarter before it actually takes place. Further, there is less need to be concerned with the details of the institutional setting. For example, if tax revenues are systematically larger in one quarter than in another quarter (this is, in particular, the case for corporate tax revenues), then a model based on quarterly data should take this feature into account. Also, with quarterly data, it is more likely that decisions on purchases take place in another quarter than when the actual outlays are done. This raises the chance that the identified shocks are wrongly dated. Finally, with annual data potential seasonality effects are absent from the data.

A drawback of using annual data is that there are fewer observations available. ${ }^{7}$ Hence, to obtain more precise estimates, we estimate the VAR model in a panel format (that is, we pool observations for a number of countries over a given sample period). The new disadvantage then is that one needs to impose cross-country homogeneity on the relationships among the variables. A number of econometric adjustments are made to deal with this objection. In particular, we include country-specific constant terms and country-specific time trends into the regression. Moreover, we include year-specific effects to eliminate any cross-country contemporaneous residual correlation. Given that the EU-14 countries share many similarities, there may then not be too much heterogeneity left. Nevertheless, we will also investigate whether the effects of an increase in government purchases depend on the degree of openness.

\subsection{Baseline impulse responses}

The set of endogenous variables in the baseline structural VAR consists of government purchases $g$, cyclically-adjusted net taxes (with country-specific cyclical adjustment) $n t$, output (GDP) $y$, the long-run nominal interest rate $\mathrm{irl}$ and the real effective exchange rate reer. ${ }^{8}$ An increase in this latter variable amounts to a real domestic depreciation. All variables are real and in natural

\footnotetext{
${ }^{6}$ The empirical relevance of the anticipation effect cannot directly be quantified. However, the results in Beetsma et al. (2009) show that fiscal plans are relatively uninformative, which suggests that the anticipation effect is limited (assuming that uninformative plans do not have substantial effects on private agents' behaviour).

${ }^{7}$ However, even if we wanted to use quarterly data, this would not be possible for the country sample under consideration. Truly quarterly data (i.e., non-interpolated data) are only available for a limited number of countries.

${ }^{8}$ Of each variable we include two lags in the regression model, which is enough to get rid of any serial correlation in the residuals. However, the results are robust to alternative lag lengths. We also check the cross-country correlations in the residuals, but in all instances these correlations are close to zero.
} 
logarithms, except for the long-run interest rate, which is in percent. The variables are entered into the vector $[g, n t, y$, irl, reer]' and identification is based on a lower-triangular Cholesky decomposition according to this particular ordering. Hence, the main identifying assumption is that government purchases are not contemporaneously affected by the other variables, in particular not by GDP. This assumption is not obviously satisfied. However, the cyclically-sensitive spending items (in particular, social benefits and other transfers) are included in net taxes, which are then cyclically adjusted. Further, changes in government purchases are usually contained in the budget law for the coming year, while adjustments during that year tend to be of less importance. Finally, indirect testing in Beetsma et al. (2008) suggests that the assumption is reasonable. ${ }^{9}$

Figure 1 depicts the impulse responses to a one-percent of GDP increase in government purchases. GDP rises significantly by 1.2 percent on impact, while it peaks at 1.5 percent after one year. ${ }^{10}$ This substantial multiplier effect is consistent with the fact that most countries in the sample have featured only limited exchange rate flexibility against their main trading partners, which in the context of a Mundell-Fleming type model would imply a short-run economic stimulus after a fiscal expansion. Cyclically-adjusted net taxes fall on impact, possibly because governments generally choose to enhance the stimulus through the increase in purchases with a reduction in the tax burden. However, unadjusted net taxes (not reported here) increase on impact. From the responses of its constituent variables, we can construct the response for the primary budget. In particular, this response is calculated as $\left(N T_{t}{ }^{N A}-G_{t}\right) / Y_{t}=\left(N T^{N A} / Y\right)\left[\left(\hat{N} T_{t}+\xi \hat{Y}_{t}\right)-\hat{Y}_{t}\right]-(G / Y)\left[\hat{G}_{t}-\hat{Y}_{t}\right]$, where $N T^{N A}, G$ and $Y$ are, respectively, the anti-logs of $n t^{N A}$ (non-cyclically-adjusted net taxes (real and in natural logarithm)), $g$ and $y$, while a hat denotes the percent deviation from the initial value (the impulse response) and $\xi$ is the elasticity of net taxes with respect to real output. We evaluate the approximation at the overall sample mean shares of $G$ and $N T^{N A}$ over $Y$. Clearly, the fiscal impulse leads to a sharp deterioration of the budget balance $(-0.7 \%$ on impact) that shrinks in the ensuing years. As far as the other variables are concerned, the long-term interest rate rises, although with some lag after the shock, suggesting the effect of a monetary tightening that also pushes up the long-run interest rate. In line with the empirical finding of Bénétrix and Lane (2009) for the euroarea and the theoretical prediction of Corsetti and Müller (2008) and Müller (2008), the real exchange rate appreciates, although the appreciation becomes significant only after three years.

\footnotetext{
${ }^{9}$ The results are also robust to a switch in the ordering of $g$ and $n t$ in the model.

${ }^{10}$ Statistical "significance" will be based on the 10 percent confidence level.
} 


\section{Figure 1: Baseline responses after a government purchases shock of $1 \%$ of GDP}
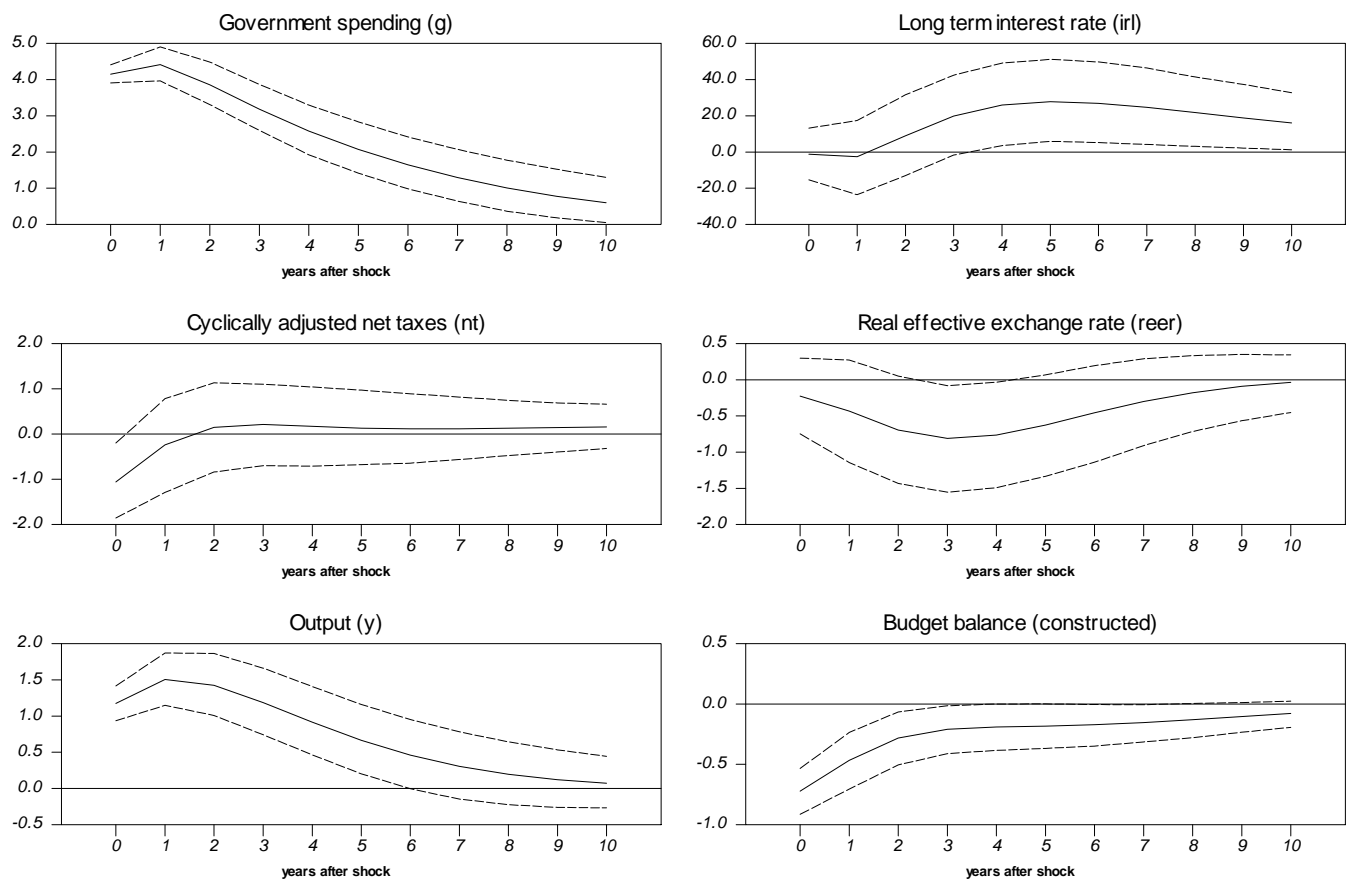

Notes: see Notes to Table 2. Confidence bands (the area between the dashed lines) are the $5^{\text {th }}$ and the $95^{\text {th }}$ percentiles from Monte Carlo simulations based on 1,000 replications. The solid line gives the median over the replications.

\section{2. “Closed" versus “open” economies}

Ideally we would want to allow for country-specific heterogeneity in the VAR parameters. However, this is practically unfeasible. Nevertheless, we can explore the consequences of some sample splits. One of the most significant differences among our countries is their degree of openness. Indeed, the theoretical discussion above implies that the effects of an increase in public purchases on the trade balance may depend on the degree of trade openness. Therefore, in this subsection we split our country-sample into “closed” and “open” economies, where those countries for which the ratio of exports plus imports over GDP has on average over time been in the upper (lower) half of the sample are classified as "open”, while the other countries are referred to as “closed”. The open economies are Austria, Belgium, Denmark, Ireland, The Netherlands, Portugal and Sweden. Table 2 reports for our baseline specification, estimated separately for each of the two groups of countries, the impulses responses to a one percent of GDP government purchases shock. 
Table 2: Responses to a government purchases increase of $1 \%$ of GDP

\begin{tabular}{|c|c|c|c|c|}
\hline & $\begin{array}{c}\text { Impact } \\
\text { Effect }\end{array}$ & $\begin{array}{c}\text { After } 1 \\
\text { year }\end{array}$ & $\begin{array}{c}\text { After } 3 \\
\text { years }\end{array}$ & $\begin{array}{c}\text { After } 5 \\
\text { years }\end{array}$ \\
\hline & \multicolumn{4}{|c|}{ (A) Baseline } \\
\hline Government purchases & $4.15^{*}$ & $4.42 *$ & $3.19 *$ & $2.07 *$ \\
\hline Net taxes & $-1.06^{*}$ & -0.24 & 0.21 & 0.13 \\
\hline Output & $1.17^{*}$ & $1.50 *$ & $1.19 *$ & $0.66^{*}$ \\
\hline Long-run interest rate & -1.19 & -2.57 & 19.86 & $27.81^{*}$ \\
\hline Real eff. exchange rate & -0.23 & -0.43 & $-0.81 *$ & -0.62 \\
\hline \multirow[t]{2}{*}{ Budget balance/GDP } & $-0.72 *$ & $-0.47^{*}$ & $-0.21 *$ & -0.18 \\
\hline & \multicolumn{4}{|c|}{ (B) “Closed” economies } \\
\hline Government purchases & $4.48 *$ & $3.99 *$ & $2.73^{*}$ & $2.08 *$ \\
\hline Net taxes & -0.57 & 0.41 & $1.63^{*}$ & $1.77^{*}$ \\
\hline Output & $1.22 *$ & $1.24 *$ & $0.93 *$ & 0.47 \\
\hline Long-run interest rate & $24.48 *$ & $29.92 *$ & 26.67 & 18.63 \\
\hline Real eff. exchange rate & -0.11 & -0.74 & $-3.00 *$ & $-2.62 *$ \\
\hline \multirow[t]{2}{*}{ Budget balance/GDP } & $-0.61 *$ & -0.29 & 0.11 & 0.09 \\
\hline & \multicolumn{4}{|c|}{ (C) “Open” economies } \\
\hline Government purchases & $3.86^{*}$ & $4.34^{*}$ & $2.78 *$ & $1.27 *$ \\
\hline Net taxes & -1.06 & $-1.90 *$ & -0.53 & 0.28 \\
\hline Output & $0.79 *$ & $0.88 *$ & 0.53 & 0.11 \\
\hline Long-run interest rate & -4.71 & -4.80 & 8.39 & 15.39 \\
\hline Real eff. exchange rate & -0.62 & -0.67 & -0.62 & -0.43 \\
\hline \multirow[t]{2}{*}{ Budget balance/GDP } & $-0.88 *$ & $-1.16^{*}$ & $-0.60 *$ & -0.21 \\
\hline & \multicolumn{4}{|c|}{ (D) Sample period $1970-1998$} \\
\hline Government purchases & $4.12 *$ & $4.68 *$ & $3.01 *$ & $1.59 *$ \\
\hline Net taxes & -0.54 & -0.24 & -0.07 & -0.05 \\
\hline Output & $1.48^{*}$ & $1.69 *$ & $1.25^{*}$ & $0.70 *$ \\
\hline Long-run interest rate & 9.52 & 12.41 & 22.88 & 21.80 \\
\hline Real eff. exchange rate & -0.71 & -0.78 & $-1.31 *$ & $-1.35^{*}$ \\
\hline \multirow[t]{2}{*}{ Budget balance/GDP } & $-0.47^{*}$ & $-0.45^{*}$ & -0.20 & -0.09 \\
\hline & \multicolumn{4}{|c|}{ (E) Sample period $1980-2004$} \\
\hline Government purchases & $4.17^{*}$ & $4.24 *$ & $3.00 *$ & $1.85^{*}$ \\
\hline Net taxes & $-1.10 *$ & -0.93 & 0.66 & $0.84^{*}$ \\
\hline Output & $1.06^{*}$ & $1.36^{*}$ & $1.02 *$ & 0.46 \\
\hline Long-run interest rate & 6.13 & 7.14 & 13.92 & 12.79 \\
\hline Real eff. exchange rate & -0.47 & $-0.94 *$ & $-1.09 *$ & $-0.74 *$ \\
\hline Budget balance/GDP & $-0.75^{*}$ & $-0.59 *$ & -0.09 & -0.03 \\
\hline
\end{tabular}

Notes: the shock is an increase in government purchases equal to $1 \%$ of GDP. Further, * denotes statistical significance at the $10 \%$ level. The impulse responses are expressed in percent of the underlying variable, except for the long-run interest rate, which is in basis points, and the budget balance/GDP ratio, which is in percentage points of GDP.

There are quite substantial differences between the impulse responses for the two groups of countries. The impact output response is weaker for the open than for the closed economies $(0.79$ versus 1.22). This is the case, despite the fact that net taxes are much more accommodative for the open economies, for which they become significantly negative after one year, while for the other group they rise above their original level after one year and become significantly positive after three years. Also the movement in the long-run interest rate is less accomodative for the closed economies. For this group its response is positive and significant during the first two years after the shock, while for the open economies its movement is a lot smaller and never significant. Finally, for 
the closed economies the real effective exchange rate exhibits a substantial and long-lasting appreciation, while for the open economies it shows relatively little movement. An explanation might be that the open economies are more exposed to foreign competition implying that the reponse of prices is more subdued (the real effective exchange rate is CPI based - see the Appendix). All three factors (net taxes, long-run interest rate and real effective exchange rate) contribute to giving the closed economies a relative disadvantage in terms of output response. The fact that the output response for this group is nevertheless quite a bit larger suggests that the leakage effect is substantially larger for the open economies.

\subsection{Different sample periods}

We now explore the robustness of our findings by varying the sample period. The first variant drops the EMU period, hence the sample runs over the years 1970-1998. The second variant drops the seventies which may be considered a somewhat unusual period because of the oil shocks. The sample period in this case is 1980-2004. This variant may also help us in detecting potential structural changes. In particular, ongoing financial innovation may have reduced credit restrictions in the private sector, making fiscal expansion less effective. There may indeed be some indication of this. The output increase is somewhat smaller for the second than for the first subperiod, despite the fact that net taxes in the short run are more accommodative for the second subperiod (see Table 2). The behavior of the other variables is quite similar for the two subsamples.

\subsection{Effects on GDP components}

Following earlier contributions in the literature, we now break up GDP into its components and we feed those separate components into the panel VAR. The vector of endogenous variables now becomes $[g, n t, x, c, i, m$, reer]', where $x$ is exports, $c$ is private consumption, $i$ is private investment and $m$ is imports, all variables being real and in natural logarithms. Identification is again based on the lower-triangular Cholesky decomposition. We include the components $x$ and $m$ of the trade balance share of GDP (tby) as separate variables in the model, in order to help us in tracing the sources of trade balance movements (and to shed light on the twin-deficits hypothesis). Further, by including consumption, we can see if we can reproduce the Keynesian effects found by, among others, Galí et al. (2007), while by incorporating investment, we can explore whether the positive short-run effects of fiscal expansion on investment, as predicted by some versions of the neo- 
classical models discussed above and the open-economy extension of Corsetti and Müller (2006), carry over to the current sample.

Figure 2 shows the impulse responses for our seven endogenous variables, as well as impulse responses for output, the budget balance and the trade balance constructed out of the responses for the endogenous variables. For the trade balance share of GDP we construct the impulse responses as $(X / Y)\left(\hat{X}_{t}-\hat{Y}_{t}\right)-(M / Y)\left(\hat{M}_{t}-\hat{Y}_{t}\right)$, where $X$ and $M$ are the anti-logs of $X$ and $m$, respectively, and evaluate this expression at the overall sample mean shares of $X$ and $M$ over $Y$. The reaction of net taxes is very similar to that under the baseline. Consumption and private investment indeed both increase, in line with the findings just recalled. In particular, the reaction of investment is strong (a peak response of 3.3\% percent after one year). Consumption reaches a peak of $1.1 \%$ after one year. The constructed GDP response resembles the corresponding response for the baseline model. Also in line with our earlier finding, the real effective exchange rate appreciates, though again with some lag. The result of this appreciation is a fall in exports that becomes significant after one period. The fall in exports is consistent with what Lane and Perotti (1998, 2003) find if the increase in government purchases falls mainly on government wage consumption. Imports rise in line with the higher income being partly spent on foreign products. Moreover, they are helped by the real exchange rate appreciation. The constructed budget balance again shows a sharp deterioration on impact, after which it restores gradually to zero. The constructed trade balance falls on impact by more than $0.5 \%$ of GDP and reaches a minimum of $0.8 \%$ of GDP. The combined effects on the budget balance and the trade balance provide support for the twin-deficits hypothesis. 
Figure 2: Effects on GDP components after a government purchases shock
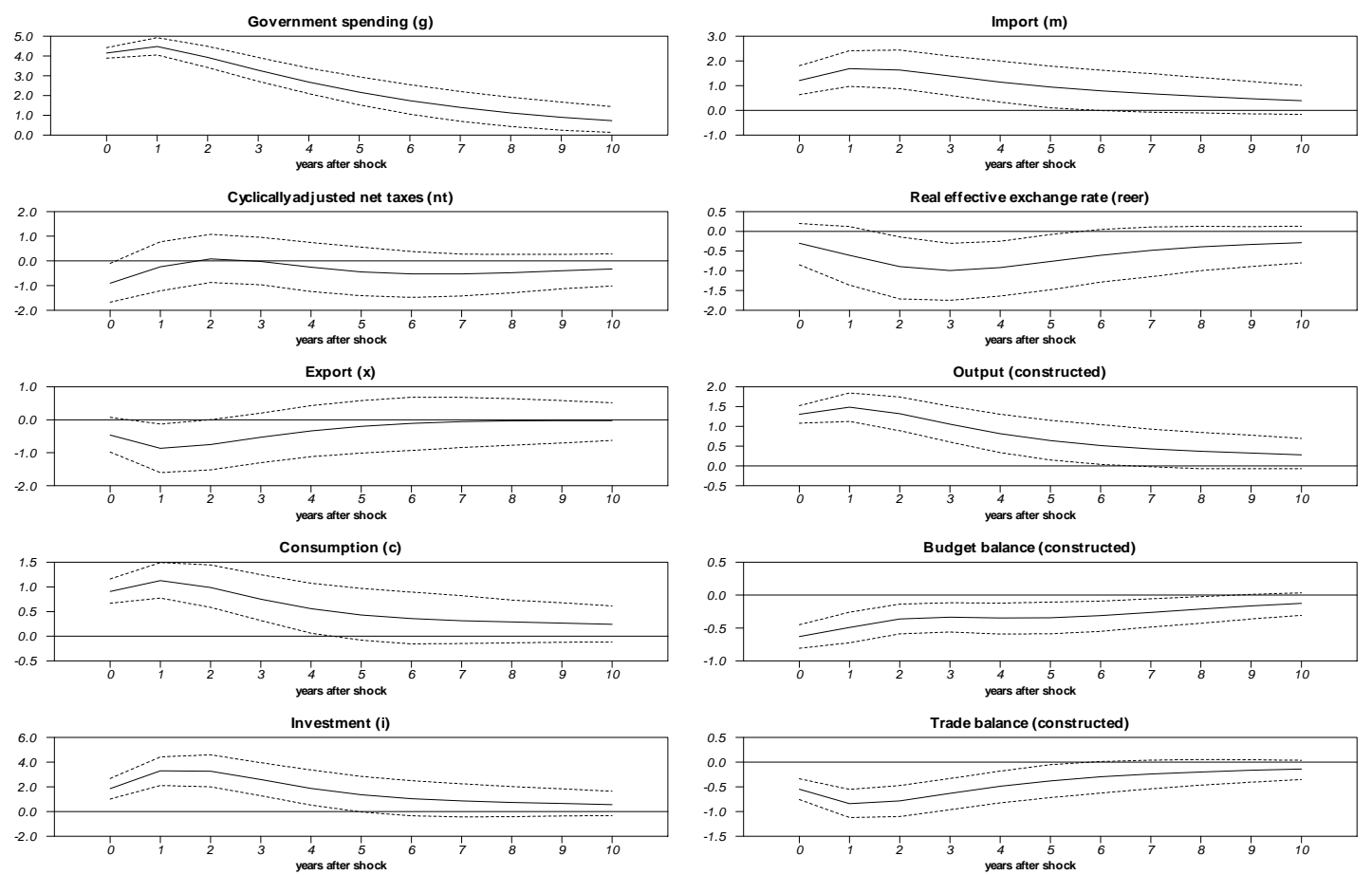

Notes: see Notes to Figure 1.

Again, we also split the sample into our groups of “closed” and "open” economies. The impulse responses for the adjusted model confirm the differences between the two groups found earlier for the baseline model. While for the closed economies consumption and investment exhibit strong positive responses (with respective peak effects of 1.5 and 4.3 percent), the corresponding responses are not significant and quantitatively small (though positive) for the other group. Again, the response of output is constructed out of the responses of its components. For the closed economies it reaches a maximum of $2.0 \%$ after a year, while for the open economies it reaches a maximum of $0.65 \%$ (achieved on impact), confirming that for this group a large fraction of the impulse leaks away. Moreover, for this group the stimulus to output fades away rather quickly. As far as the effects on the public budget are concerned, for both groups it deteriorates on impact, although the effect is more than twice as large for the open economies. Moreover, for the closed economies the budget is back into balance after one year, while for the open economies it deteriorates further and only returns to balance in the medium run. One reason for the larger immediate deterioration for the open economies is the smaller increase in GDP. The other is the substantial reduction in net taxes for these economies, which becomes significant after one year. Finally, comparing the effects on the trade balance as a share of GDP, we see that the reduction is larger in magnitude for the open than for closed economies (at least over the first two years). A 
major source of the fall in the trade balance is the rise in imports, which in turn is to a large extent driven by an increase in GDP. Hence, the substantially-larger GDP response for the closed economies likely suppresses the difference in trade balance responses between the two groups of economies.

\subsection{Including EU goods trade only}

The trade data used so far include both trade in goods and services and cover the total of exports and imports of the sample countries. However, data on cross-border trade in goods would generally be considered more reliable than data also covering services trade. In fact, most of the international trade is trade in goods. In our sample imports and exports of goods are on average 28\% of GDP, while the corresponding figure for services is about $5 \%$ on average. Further, because we are interested in the benefits of fiscal stimulus for EU partner countries, we limit ourselves now to (goods) exports to and imports from EU countries only. We are no longer directly interested in consumption and investment. Hence, for the sake of parsimony we do not include these components in the panel VAR, but instead include GDP. Hence, the vector of endogenous variables becomes $[g$, $n t, x^{E U}, y, m^{E U}$, reer $\left.{ }^{E U}\right]^{\prime}$, where $x^{E U}\left(m^{E U}\right)$ is good exports (imports) to (from) all other EU countries in the sample, and reer ${ }^{E U}$ is the real effective exchange rate with respect to all other EU sample countries. The impulse responses are reported in panel (D) of Table 3. Compared with the results reported in panel (A) of this table, the negative response of exports and the appreciation of the real effective exchange rate are no longer significant, while imports react more strongly, suggesting a higher elasticity (to domestic output) of imports from the EU than from other countries. 
Table 3: Responses to a government purchases increase - GDP split into components

\begin{tabular}{|c|c|c|c|c|}
\hline & $\begin{array}{c}\text { Impact } \\
\text { Effect }\end{array}$ & $\begin{array}{c}\text { After } 1 \\
\text { year }\end{array}$ & $\begin{array}{c}\text { After } 3 \\
\text { years }\end{array}$ & $\begin{array}{c}\text { After } 5 \\
\text { years }\end{array}$ \\
\hline & \multicolumn{4}{|c|}{ (A) All countries } \\
\hline Government purchases & $4.15^{*}$ & $4.49 *$ & $3.28 *$ & $2.17 *$ \\
\hline Net taxes & $-0.90 *$ & -0.24 & -0.02 & -0.44 \\
\hline Exports & -0.46 & $-0.87^{*}$ & -0.53 & -0.20 \\
\hline Consumption & $0.91 *$ & $1.13^{*}$ & $0.75^{*}$ & 0.43 \\
\hline Investment & $1.85^{*}$ & $3.30 *$ & $2.59 *$ & 1.36 \\
\hline Imports & $1.21^{*}$ & $1.69 *$ & $1.39 *$ & $0.94 *$ \\
\hline Real eff. exchange rate & -0.30 & -0.61 & $-0.99 *$ & $-0.76^{*}$ \\
\hline Output & $1.31^{*}$ & $1.49 *$ & $1.06 *$ & $0.64 *$ \\
\hline Budget balance/GDP & $-0.63 *$ & $-0.49 *$ & $-0.34 *$ & $-0.34 *$ \\
\hline \multirow[t]{2}{*}{ Trade balance/GDP } & $-0.55^{*}$ & $-0.84^{*}$ & $-0.63^{*}$ & $-0.38^{*}$ \\
\hline & \multicolumn{4}{|c|}{ (B) “Closed" economies } \\
\hline Government purchases & $4.48^{*}$ & $4.04^{*}$ & $2.85 *$ & $1.96^{*}$ \\
\hline Net taxes & -0.75 & 0.75 & 0.01 & -0.79 \\
\hline Exports & -0.58 & -1.16 & -0.48 & -0.58 \\
\hline Consumption & $1.36^{*}$ & $1.46^{*}$ & $0.91 *$ & 0.61 \\
\hline Investment & $2.28 *$ & $4.22 *$ & $3.32 *$ & $2.16^{*}$ \\
\hline Imports & $1.08 *$ & 0.93 & $1.26^{*}$ & 0.87 \\
\hline Real eff. exchange rate & -0.31 & -1.00 & $-1.96 *$ & $-1.72 *$ \\
\hline Output & $1.82 *$ & $2.03 *$ & $1.36^{*}$ & $0.84 *$ \\
\hline Budget balance/GDP & $-0.40^{*}$ & 0.09 & -0.07 & -0.25 \\
\hline \multirow[t]{2}{*}{ Trade balance/GDP } & $-0.39 *$ & $-0.49 *$ & $-0.41^{*}$ & $-0.34^{*}$ \\
\hline & \multicolumn{4}{|c|}{ (C) “Open” economies } \\
\hline Government purchases & $3.86^{*}$ & $4.23 *$ & $2.66 *$ & 1.06 \\
\hline Net taxes & -0.87 & $-1.81^{*}$ & -0.36 & 0.28 \\
\hline Exports & -0.71 & -0.64 & -0.63 & -0.61 \\
\hline Consumption & 0.21 & 0.41 & 0.15 & -0.18 \\
\hline Investment & 0.40 & 0.50 & 0.01 & -0.99 \\
\hline Imports & 0.50 & $1.37 *$ & 0.55 & -0.51 \\
\hline Real eff. exchange rate & -0.61 & -0.64 & -0.43 & -0.32 \\
\hline Output & $0.65 *$ & $0.53 *$ & 0.25 & -0.05 \\
\hline Budget balance/GDP & $-0.90 *$ & $-1.27^{*}$ & $-0.66^{*}$ & -0.23 \\
\hline \multirow[t]{2}{*}{ Trade balance/GDP } & $-0.54 *$ & $-0.89 *$ & $-0.53^{*}$ & -0.05 \\
\hline & \multicolumn{4}{|c|}{ (D) Only EU goods trade } \\
\hline Government purchases & $4.15^{*}$ & $4.36 *$ & 3.18* & $2.07 *$ \\
\hline Net taxes & $-1.12 *$ & -0.33 & 0.43 & 0.29 \\
\hline Goods exports to EU & -0.21 & -0.63 & -0.47 & -0.25 \\
\hline Output & $1.18^{*}$ & $1.54^{*}$ & $1.24^{*}$ & $0.74^{*}$ \\
\hline Goods imports from EU & $2.30 *$ & $2.99 *$ & $2.76^{*}$ & $1.78^{*}$ \\
\hline REER w.r.t. EU & -0.06 & -0.32 & -0.47 & -0.15 \\
\hline Budget balance/GDP & $-0.74 *$ & $-0.46^{*}$ & -0.14 & -0.12 \\
\hline Trade balance/GDP & $-0.46 *$ & $-0.67 *$ & $-0.60 *$ & $-0.38 *$ \\
\hline
\end{tabular}

Notes: see Notes to Table 2. The trade balance is expressed in percentage points of GDP. Further, the responses for output (except in case (D)), the budget balance and the trade balance are constructed out of their components. Finally, "REER" = real effective exchange rate.

\subsection{Direct estimates of spill-overs}

Some of the EU countries are reluctant to expand fiscal policy in response to the current crisis, because they fear that a large part of the stimulus leaks abroad. Individual governments generally 
do not internalize those external benefits of a national fiscal expansion. When viewed from an aggregative (European) perspective, the result may then well be too little fiscal stimulus, at least in the current economic circumstances. This may explain why the European Commission (2008) has taken its initiative for the EERP. The Commission works for the entire EU and, as such, it is supposed to internalise all externalities. To form an idea about the potential gains from the coordination of fiscal stimulus, we expand the baseline model with the variable $y^{*}$, which is a measure of economic activity in the other EU countries. Specifically, the vector of endogenous variables becomes now $\left[y^{*}, g, n t, y, i r l, r e e r\right]^{\prime}$. We allow for both a response of $y^{*}$ to $y$ as well as a response of $y$ to $y^{*}$. This introduces an extra parameter above the "diagonal". With the remainder of the identication scheme following the lower-triangular Cholesky decomposition we need an additional restriction. This is achieved by imposing a zero restriction on the response of $g$ to $y^{*}$. Given that we have throughout assumed that $g$ does not contemporaneously react to $y$, it seems most reasonable to also assume that it does not contemporaneously react to $y^{*}{ }^{* 11}$

In exploring the international spill-over effects we confine ourselves to government purchases impulses originating in the five largest EU economies (France, Germany, Italy, Spain and the U.K.). Together, these economies make up a large fraction of the entire EU economy, while, moreover we expect the international consequences of individual fiscal impulses in small countries to be small, thereby driving down the estimated average spill-over. We thus estimate a panel VAR with five of these countries. Figure 3 shows the impulse responses for the two weighting schemes used to construct the rest-of-Europe output. The first scheme is based on GDP weights, while the second one is based on the intensity of bilateral trade relationships. In particular, we use a weighting scheme based on the amounts of imports by the impulse-giving country (see the Appendix). The extended specification reproduces the baseline results. The effects on domestic output have become even somewhat stronger on impact and one year after the shock, possibly because these large economies are even more closed on average than the "average" closed economy in our sample.

When based on GDP weights, rest-of-EU output goes up in response to the domestic shock, although the rise is not statistically significant (see Figure 3(a)). With foreign output based on imports weights, not surprisingly the effect on rest-of-EU output is larger (see Figure 3(b)). Two years after the shock it reaches a significant peak if we consider a confidence interval of minus/plus one standard error around the mean $\left(16-84^{\text {th }}\right.$ percentile), as has become rather standard now in this literature. The peak effect of 0.35 is quite substantial if we realise that this number reflects the spillover of a unilateral fiscal expansion (though of a large economy). Hence, on the basis of these

\footnotetext{
${ }^{11}$ To avoid collinearity problems due to the high correlation between the time effects and the rest-of-Europe output (which is almost country-invariant), period effects are excluded from this specification.
} 
results, spill-overs of a concerted fiscal expansion in the largest five EU countries can be expected to be quite substantial.

Figure 3: System with spill-overs

\section{a. GDP-based weights of foreign GDP}
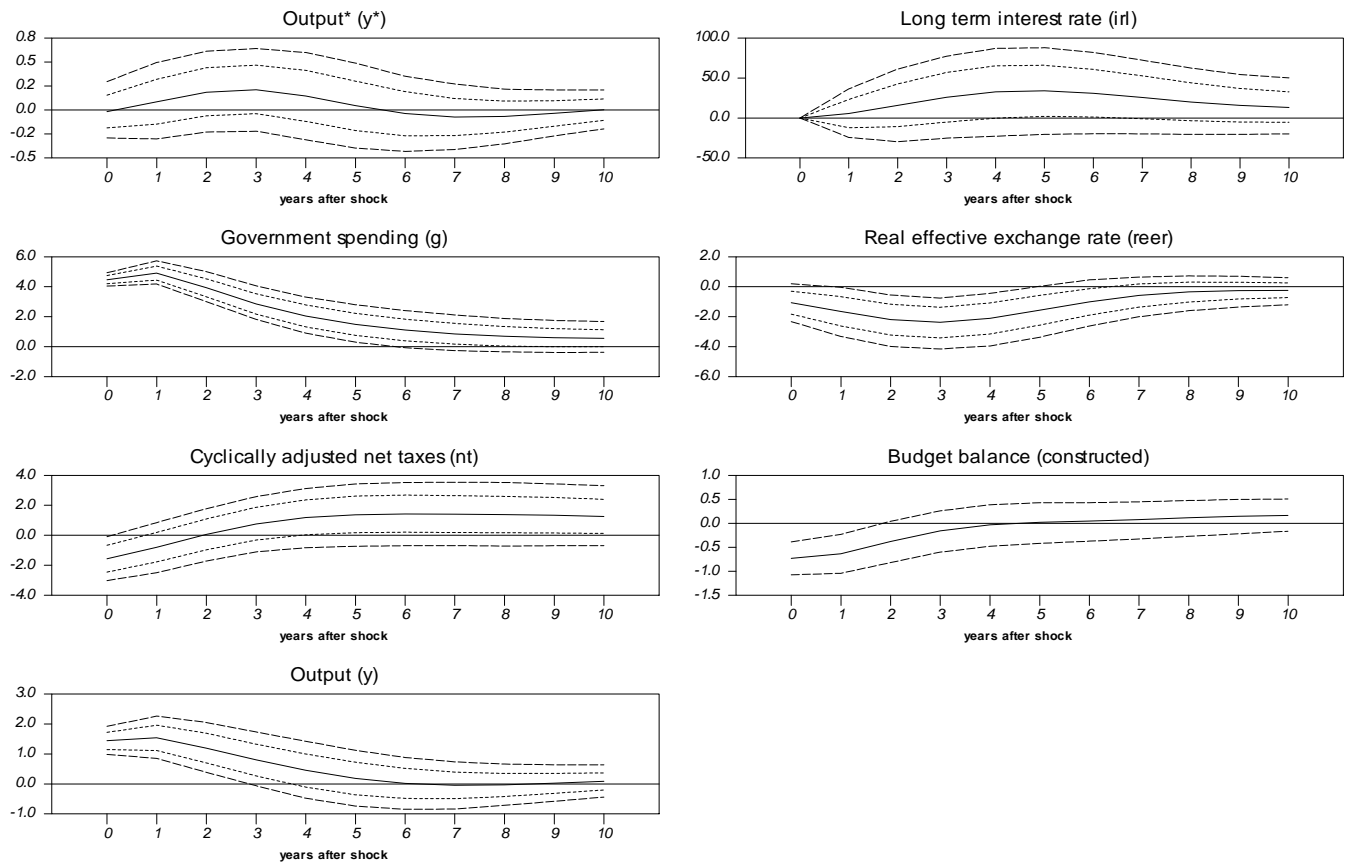

\section{b. Trade-based weights of foreign GDP}
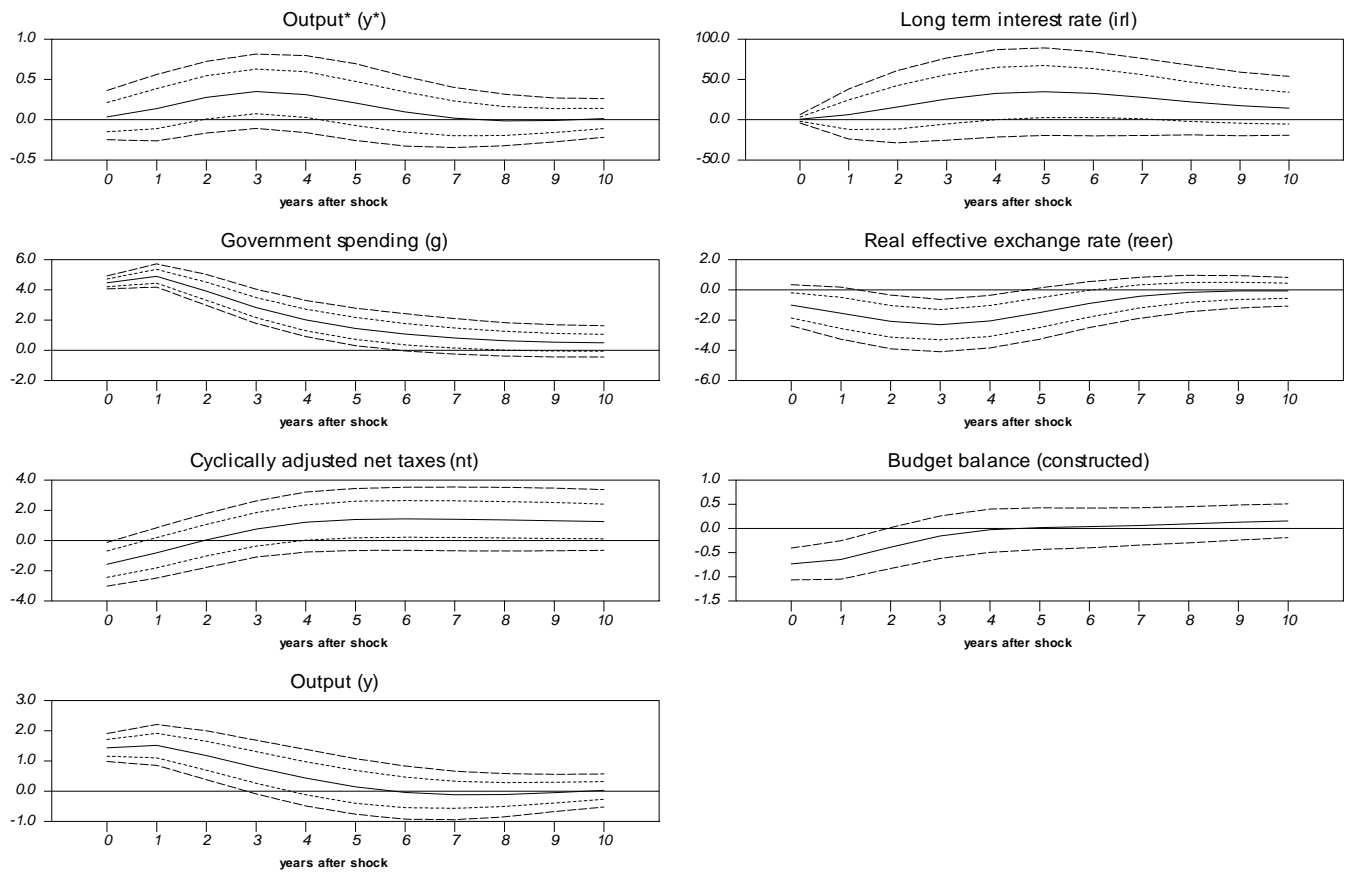

Notes: see Notes to Figure 1 . The area between the dotted lines is the confidence interval based on minus/plus onestandard error (i.e. $16-84^{\text {th }}$ percentile), while the dashed line gives the $90 \%$ confidence interval (5-95 ${ }^{\text {th }}$ percentile). 


\section{Concluding remarks}

This paper has briefly reviewed the theoretical and empirical literature on the effects of discretionary fiscal expansions on the economy. Employing panel VARs we have then provided our own evidence for the EU on the consequences of a discretionary increase in government purchases. We find a positive effect on output with a multiplier of more than unity for the entire sample. The real exchange rate appreciates and the public budget deteriorates. A split of output into its components suggests positive responses of private consumption and investments, while imports rise and exports fall, implying a deterioration of the trade balance and, hence, lending support to the twin-deficits hypothesis. A sample split into relatively closed and relatively open economies suggests a lower output multiplier for the latter group, which in turn indicates that for this group a substantial part of the fiscal stimulus leaks abroad.

Further investigation shows that import elasticities for within-EU trade are higher than for trade with countries outside the EU. In our more explicit search for cross-border spill-over effects we found indications of non-negligle effects of national fiscal expansion on other EU countries, in particular the main trading partners. These results provide a rationale for the EERP, which envisages a concerted fiscal response to the current economic crisis. Of course, one should be careful in advising substantial joint fiscal expansion, as budget deficits are ballooning and the future consequences in terms of debt repayment may be quite severe.

\section{References}

Alesina, A., Ardagna, S., Perotti, R. and F. Schiantarelli (2002), Fiscal Policy, Profits, and Investment, American Economic Review 92, 571-589.

Baxter, M. (1995), International Trade and Business Cycles, in Grossman, Gene M. and Kenneth Rogoff (eds.), Handbook of International Economics, Amsterdam; North-Holland, 1801-1864.

Baxter, M. and R.G. King (1993), Fiscal Policy in General Equilibrium, American Economic Review, 83, 315-334.

Beetsma, R., Giuliodori, M. and F. Klaassen (2008), The Effects of Public Spending Shocks on Trade Balances and Budget Deficits in the EU, Journal of the European Economic Association 6, 2-3, 414-423. 
Beetsma, R., Giuliodori, M. and P. Wierts (2009), Planning to Cheat: EU Fiscal Policy in Real Time, Economic Policy, forthcoming.

Beetsma, R. and H. Jensen (2005), Monetary and Fiscal Policy Interactions in a Micro-founded Model of a Monetary Union, Journal of International Economics 67, 320-352.

Bénétrix, A.S., and P. Lane (2009), Fiscal Shocks and the Real Exchange Rate, IIIS Discussion Paper, No. 286, March.

Blanchard, O. and R. Perotti (2002), An Empirical Characterization of the Dynamic Effects of Changes in Government Spending and Taxes on Output, Quarterly Journal of Economics 117, 1329-1368.

Burnside, C., Eichenbaum, M. and J.D.M. Fisher (2004), Fiscal Shocks and their Consequences, Journal of Economic Theory 115, 89-117.

Bun, M.J.G. and F.J.G.M Klaassen (2007), The Euro Effect on Trade is not as Large as Commonly Thought, Oxford Bulletin of Economics and Statistics 69, 473-496.

Corsetti, G. and G. Müller (2008), Twin Deficits, Openness, and the Business Cycle, Journal of the European Economic Association 6, 2-3, 404-413.

Devereux, M.B., Head, A.C. and B.J. Lapham (1996), Monopolistic Competition, Increasing Returns, and the Effects of Government Spending, Journal of Money, Credit, and Banking 28, 2, 233-254.

European Commission (2008), A European Economic Recovery Plan, http://ec.europa.eu/economy_finance/publications/publication13504_en.pdf .

Edelberg, W., Eichenbaum, M. and J.D.M. Fisher (1999), Understanding the Effects of a Shock to Government Purchases, Review of Economic Dynamics 2, 166-206.

Fatás, A. and I. Mihov (2001), The Effects of Fiscal Policy on Consumption and Employment: Theory and Evidence, CEPR Discussion Paper, No. 2760.

Galí, J., Vallés, J. and J.D. López-Salido (2007), Understanding the Effects of Government Spending on Consumption, Journal of the European Economic Association 5, 1, 227-70.

Gemmell, N., Kneller, R. and I. Sanz (2009), The Timing and Persistence of Fiscal Policy Impacts on Growth: Evidence from OECD Countries, Mimeo, New Zealand Treasury/University of Nottingham/Universidad Complutense de Madrid.

Heady, C., Johansson, A., Arnold, J., Brys, B. and L. Vartia (2009), Tax Policy for Economic Recovery and Growth, Mimeo, University of Kent/OECD.

Kim, S. and N. Roubini (2008), Twin Deficit or Twin Divergence? Fiscal Policy, Current Account, and Real Exchange Rate in the U.S., Journal of International Economics 74, 2, 362-383. 
Lane, P. and R. Perotti (1998), The Trade Balance and Fiscal Policy in the OECD, European Economic Review 42, 887-895.

Lane, P. and R. Perotti (2003), The Importance of Composition of Fiscal Policy: Evidence from Different Exchange Rate Regimes, Journal of Public Economics 87, 2253-79.

Linnemann, L. (2006), The Effect of Government Spending on Private Consumption: A Puzzle?, Journal of Money, Credit, and Banking 38, 7, 1715-35.

Monacelli, T. and R. Perotti (2006), Fiscal Policy, the Trade Balance and the Real Exchange Rate: Implications for International Risk Sharing, Mimeo, IGIER.

Mountford, A. and H. Uhlig (2009), What are the Effects of Fiscal Policy Shocks? Journal of Applied Econometrics, forthcoming.

Müller, G. (2008), Understanding the Dynamic Effects of Government Spending on Foreign Trade, Journal of International Money and Finance 27, 3, 345-371.

OECD (2005), Economic Outlook, June, Paris.

Pappa, E. (2006), Discussion of "Comparing Alternative Methodologies to Estimate the Effects of Fiscal Policy by Roberto Perotti”, Mimeo, London School of Economics.

Ramey, V. and M. Shapiro (1998), Costly Capital Reallocation and the Effects of Government Spending, Carnegie-Rochester Series on Public Policy 48, 145-94.

Ravn, M., Schmitt-Grohé, S. and M. Uribe (2006), Deep Habits, Review of Economic Studies 73, 1, 195-218.

Ravn, M., Schmitt-Grohé, S. and M. Uribe (2007), Explaining the Effects of Government Spending Shocks on Consumption and the Real Exchange Rate, Mimeo, EUI Florence and Duke University.

Van den Noord, P. (2000), The Size and Role of Automatic Fiscal Stabilizers in the 1990s and Beyond, OECD Working Paper, No.230.

\section{Appendix}

Data sources are the OECD Economic Outlook (EO) (Vol. 76), the Main Economic Indicators (MEI) of the OECD Statistical Compendium and the IMF's Direction of Trade Statistics (DOTS).

\section{Fiscal variables}

The EO provides time series at annual frequency for the following variables:

CGAA = Government Consumption 


$\begin{array}{lll}I G A A & = & \text { Fixed Investment, Government } \\ P C G & = & \text { Deflator, Public Consumption (base year 1995 =100) } \\ \text { PIG } & = & \text { Deflator, Government Fixed Investment (base year 1995 =100) } \\ \text { TIND } & = & \text { Indirect Taxes } \\ T S U B & = & \text { Subsidies } \\ T Y & = & \text { Direct Taxes } \\ \text { SSPG } & = & \text { Social Benefits Paid by Government } \\ T R P G & = & \text { Other Current Transfers Paid by Government } \\ S S R G & = & \text { Social Security Contributions Received by Government } \\ T R R G & = & \text { Other Current Transfers Received by Government }\end{array}$

Additional variables

$\begin{array}{lll}G D P & = & \text { Gross Domestic Product (Market Prices), Value } \\ G D P V & = & \text { Gross Domestic Product (Market Prices), Volume } \\ C P V & = & \text { Private Final Consumption Expenditure, Volume } \\ I P V & = & \text { Private Total Fixed Capital Formation, Volume } \\ X G S V & = & \text { Exports of Goods and Services, Volume, National Account Basis } \\ M G S V & = & \text { Imports of Goods and Services, Volume, National Account Basis } \\ P G D P & = & \text { Deflator for GDP at Market Prices (base year 1995 =100) } \\ I R L & = & \text { Long term interest rate } \\ R E E R & = & \text { Real Effective Exchange Rate (based on consumer price index) }\end{array}$

From the above series, we construct the following variables:

\begin{tabular}{|c|c|c|}
\hline$G$ & $=$ & $C G A A^{*} 100 / P C G+I G A A^{*} 100 / P I G$ \\
\hline REVENUES & $=$ & $T Y+T I N D+S S R G+T R R G$ \\
\hline TRANFERS & $=$ & $T S U B+S S P G+T R P G$ \\
\hline$N T^{N A}$ & $=$ & $($ REVENUES - TRANFERS)*100/PGDP \\
\hline
\end{tabular}

Due to short data availability, for Ireland and the Netherlands TRPG and TRRG are not included in the calculation of REVENUES and TRANFERS.

\section{Cyclical adjustment}

In order to cyclically adjust net taxes, we follow Alesina et al. (2002) and for each component $R_{i}$ of revenues and transfers at time $t$ we compute: 
$R_{i t}^{C A}=R_{i t}^{N A}\left(Y_{t}^{T R} / Y_{t}\right)^{\xi_{i}}$

where superscripts $C A, N A$ and $T R$ denote, respectively, "cyclically adjusted”, "non-cyclically adjusted" and "trend", and $\xi$ is the elasticity of component $i$ with respect to the real level of output $Y$. Elasticities are provided by Van den Noord (2000) and the OECD (2005). However, the OECD does not provide the transfers elasticity. Therefore, as in Alesina et al. (2002), we use the total primary expenditure elasticity and scale it up by the ratio of transfers to total primary spending. Additionally, we calculate trend GDP separately for each country by regressing log real GDP on a constant, a linear and a quadratic time trend. Real cyclically-adjusted net taxes $\left(N T^{C A}\right)$ are constructed as the sum of the cyclically-adjusted components $R_{i}^{C A}$, deflated with the GDP deflator $(P G D P)$.

\section{Trade variables}

These data are taken from Bun and Klaassen (2007) updated with the years 2003 and 2004. Real imports $\left(M G V^{E U}\right)$ and exports $\left(X G V^{E U}\right)$ of goods from and to the EU countries are based on real bilateral export flows, which are constructed as the sum of the monthly real exports, where the latter is the nominal value of exports in exporter's currency divided by the exporter's price index. The nominal value of exports in exporter's currency is obtained by converting the original dollar denominated export values of the DOTS. The real effective exchange rate with respect to the other EU countries ( $R E E R^{E U}$ ) is the weighted average of the bilateral real exchange rates (using export shares as weights). The latter are the average of the monthly real rates computed using nominal exchange rates and the consumer price indices (CPIs) of the countries involved. To the extent CPIs were not available, wholesale price indices are used.

\section{Rest-of-Europe output}

For each large country $i$ (France, Germany, Italy, Spain and the U.K.), rest-of-Europe output ( $\left.Y_{i t}^{*}\right)$ is constructed as the weighted average of the domestic real GDP indices of the other EU countries $j$. The index for country $j$ is $Y_{j t}^{\text {index }}=Y_{j t} / Y_{j}$, where $Y_{j}$ is the level of GDP in the base year (2004) expressed in euros. Hence, $Y_{i t}^{*}=\sum_{j=1}^{14} w_{i j} Y_{j t}^{\text {index }}$ where $\sum_{j=1}^{14} w_{i j}=1$ and $w_{i j}=0$ if $j=i$.

We consider two weighting schemes. The first is based on real GDP levels in the base year. Hence, in this case, $w_{i j}=Y_{j} /\left(\sum_{j=1}^{14} Y_{j}\right)$ if $j \neq i$, and $w_{i j}=0$ if $j=i$. The second scheme is based on 
the bilateral import relationships. Countries with a stronger trade relationship with the home country get a larger weight. In this case, the weights are computed as $w_{i j}=M_{i j} /\left(\sum_{j=1}^{14} M_{i j}\right)$ if $j \neq i$, and $w_{i j}=0$ if $j=i$. Here, $M_{i j}$ is the level of imports of country $i$ from country $j$ in the base year 2003 expressed in dollars.

Variables used in the panel estimation

$y=\ln (G D P V), c=\ln (C P V), i=\ln (I P V), m=\ln (M G S V), x=\ln (X G S V), m^{E U}=\ln \left(M G V^{E U}\right), x^{E U}=$ $\ln \left(X G V^{E U}\right)$, irl $=I R L$, reer $=\ln (R E E R)$, reer $^{E U}=\ln \left(R E E R^{E U}\right), g=\ln (G), n t=\ln \left(N T^{C A}\right), y^{*}=$ $\ln \left(Y^{*}\right)$.

\section{Data sample:}

The PVAR is estimated for 14 EU countries: Austria, Belgium, Denmark, Finland, France, Germany, Greece, Ireland, Italy, Netherlands, Portugal, Spain, Sweden and the United Kingdom. The estimation sample is 1970-2004. The only exceptions are Denmark (1971-2004), the United Kingdom (1972-2004), Ireland (1977-2004) and Portugal (1977-2004). 


\section{CESifo Working Paper Series}

for full list see www.cesifo-group.org/wp

(address: Poschingerstr. 5, 81679 Munich, Germany, office@cesifo.de)

2885 Charles A.E. Goodhart, Carolina Osorio and Dimitrios P. Tsomocos, Analysis of Monetary Policy and Financial Stability: A New Paradigm, December 2009

2886 Thomas Aronsson and Erkki Koskela, Outsourcing, Public Input Provision and Policy Cooperation, December 2009

2887 Andreas Ortmann, "The Way in which an Experiment is Conducted is Unbelievably Important": On the Experimentation Practices of Economists and Psychologists, December 2009

2888 Andreas Irmen, Population Aging and the Direction of Technical Change, December 2009

2889 Wolf-Heimo Grieben and Fuat Şener, Labor Unions, Globalization, and Mercantilism, December 2009

2890 Conny Wunsch, Optimal Use of Labor Market Policies: The Role of Job Search Assistance, December 2009

2891 Claudia Buch, Cathérine Tahmee Koch and Michael Kötter, Margins of International Banking: Is there a Productivity Pecking Order in Banking, too?, December 2009

2892 Shafik Hebous and Alfons J. Weichenrieder, Debt Financing and Sharp Currency Depreciations: Wholly vs. Partially Owned Multinational Affiliates, December 2009

2893 Johannes Binswanger and Daniel Schunk, What is an Adequate Standard of Living during Retirement?, December 2009

2894 Armin Falk and James J. Heckman, Lab Experiments are a Major Source of Knowledge in the Social Sciences, December 2009

2895 Hartmut Egger and Daniel Etzel, The Impact of Trade on Employment, Welfare, and Income Distribution in Unionized General Oligopolistic Equilibrium, December 2009

2896 Julian Rauchdobler, Rupert Sausgruber and Jean-Robert Tyran, Voting on Thresholds for Public Goods: Experimental Evidence, December 2009

2897 Michael McBride and Stergios Skaperdas, Conflict, Settlement, and the Shadow of the Future, December 2009

2898 Ben J. Heijdra and Laurie S. M. Reijnders, Economic Growth and Longevity Risk with Adverse Selection, December 2009

2899 Johannes Becker, Taxation of Foreign Profits with Heterogeneous Multinational Firms, December 2009 
2900 Douglas Gale and Piero Gottardi, Illiquidity and Under-Valuation of Firms, December 2009

2901 Donatella Gatti, Christophe Rault and Anne-Gaël Vaubourg, Unemployment and Finance: How do Financial and Labour Market Factors Interact?, December 2009

2902 Arno Riedl, Behavioral and Experimental Economics Can Inform Public Policy: Some Thoughts, December 2009

2903 Wilhelm K. Kohler and Marcel Smolka, Global Sourcing Decisions and Firm Productivity: Evidence from Spain, December 2009

2904 Marcel Gérard and Fernando M. M. Ruiz, Corporate Taxation and the Impact of Governance, Political and Economic Factors, December 2009

2905 Mikael Priks, The Effect of Surveillance Cameras on Crime: Evidence from the Stockholm Subway, December 2009

2906 Xavier Vives, Asset Auctions, Information, and Liquidity, January 2010

2907 Edwin van der Werf, Unilateral Climate Policy, Asymmetric Backstop Adoption, and Carbon Leakage in a Two-Region Hotelling Model, January 2010

2908 Margarita Katsimi and Vassilis Sarantides, Do Elections Affect the Composition of Fiscal Policy?, January 2010

2909 Rolf Golombek, Mads Greaker and Michael Hoel, Climate Policy without Commitment, January 2010

2910 Sascha O. Becker and Ludger Woessmann, The Effect of Protestantism on Education before the Industrialization: Evidence from 1816 Prussia, January 2010

2911 Michael Berlemann, Marco Oestmann and Marcel Thum, Demographic Change and Bank Profitability. Empirical Evidence from German Savings Banks, January 2010

2912 Øystein Foros, Hans Jarle Kind and Greg Shaffer, Mergers and Partial Ownership, January 2010

2913 Sean Holly, M. Hashem Pesaran and Takashi Yamagata, Spatial and Temporal Diffusion of House Prices in the UK, January 2010

2914 Christian Keuschnigg and Evelyn Ribi, Profit Taxation and Finance Constraints, January 2010

2915 Hendrik Vrijburg and Ruud A. de Mooij, Enhanced Cooperation in an Asymmetric Model of Tax Competition, January 2010

2916 Volker Meier and Martin Werding, Ageing and the Welfare State: Securing Sustainability, January 2010 
2917 Thushyanthan Baskaran and Zohal Hessami, Globalization, Redistribution, and the Composition of Public Education Expenditures, January 2010

2918 Angel de la Fuente, Testing, not Modelling, the Impact of Cohesion Support: A Theoretical Framework and some Preliminary Results for the Spanish Regions, January 2010

2919 Bruno S. Frey and Paolo Pamini, World Heritage: Where Are We? An Empirical Analysis, January 2010

2920 Susanne Ek and Bertil Holmlund, Family Job Search, Wage Bargaining, and Optimal Unemployment Insurance, January 2010

2921 Mariagiovanna Baccara, Allan Collard-Wexler, Leonardo Felli and Leeat Yariv, Gender and Racial Biases: Evidence from Child Adoption, January 2010

2922 Kurt R. Brekke, Roberto Cellini, Luigi Siciliani and Odd Rune Straume, Competition and Quality in Regulated Markets with Sluggish Demand, January 2010

2923 Stefan Bauernschuster, Oliver Falck and Niels Große, Can Competition Spoil Reciprocity? - A Laboratory Experiment, January 2010

2924 Jerome L. Stein, A Critique of the Literature on the US Financial Debt Crisis, January 2010

2925 Erkki Koskela and Jan König, Profit Sharing, Wage Formation and Flexible Outsourcing under Labor Market Imperfection, January 2010

2926 Gabriella Legrenzi and Costas Milas, Spend-and-Tax Adjustments and the Sustainability of the Government's Intertemporal Budget Constraint, January 2010

2927 Piero Gottardi, Jean Marc Tallon and Paolo Ghirardato, Flexible Contracts, January 2010

2928 Gebhard Kirchgässner and Jürgen Wolters, The Role of Monetary Aggregates in the Policy Analysis of the Swiss National Bank, January 2010

2929 J. Trent Alexander, Michael Davern and Betsey Stevenson, Inaccurate Age and Sex Data in the Census PUMS Files: Evidence and Implications, January 2010

2930 Stefan Krasa and Mattias K. Polborn, Competition between Specialized Candidates, January 2010

2931 Yin-Wong Cheung and Xingwang Qian, Capital Flight: China's Experience, January 2010

2932 Thomas Hemmelgarn and Gaetan Nicodeme, The 2008 Financial Crisis and Taxation Policy, January 2010 
2933 Marco Faravelli, Oliver Kirchkamp and Helmut Rainer, Social Welfare versus Inequality Concerns in an Incomplete Contract Experiment, January 2010

2934 Mohamed El Hedi Arouri and Christophe Rault, Oil Prices and Stock Markets: What Drives what in the Gulf Corporation Council Countries?, January 2010

2935 Wolfgang Lechthaler, Christian Merkl and Dennis J. Snower, Monetary Persistence and the Labor Market: A New Perspective, January 2010

2936 Klaus Abberger and Wolfgang Nierhaus, Markov-Switching and the Ifo Business Climate: The Ifo Business Cycle Traffic Lights, January 2010

2937 Mark Armstrong and Steffen Huck, Behavioral Economics as Applied to Firms: A Primer, February 2010

2938 Guglielmo Maria Caporale and Alessandro Girardi, Price Formation on the EuroMTS Platform, February 2010

2939 Hans Gersbach, Democratic Provision of Divisible Public Goods, February 2010

2940 Adam Isen and Betsey Stevenson, Women's Education and Family Behavior: Trends in Marriage, Divorce and Fertility, February 2010

2941 Peter Debaere, Holger Görg and Horst Raff, Greasing the Wheels of International Commerce: How Services Facilitate Firms' International Sourcing, February 2010

2942 Emanuele Forlani, Competition in the Service Sector and the Performances of Manufacturing Firms: Does Liberalization Matter?, February 2010

2943 James M. Malcomson, Do Managers with Limited Liability Take More Risky Decisions? An Information Acquisition Model, February 2010

2944 Florian Englmaier and Steve Leider, Gift Exchange in the Lab - It is not (only) how much you give ..., February 2010

2945 Andrea Bassanini and Giorgio Brunello, Barriers to Entry, Deregulation and Workplace Training: A Theoretical Model with Evidence from Europe, February 2010

2946 Jan-Emmanuel De Neve, James H. Fowler and Bruno S. Frey, Genes, Economics, and Happiness, February 2010

2947 Camille Cornand and Frank Heinemann, Measuring Agents' Reaction to Private and Public Information in Games with Strategic Complementarities, February 2010

2948 Roel Beetsma and Massimo Giuliodori, Discretionary Fiscal Policy: Review and Estimates for the EU, February 2010 